\title{
PENERAPAN MODEL PEMBELAJARAN KOOPERATIF TIPE STUDENT TEAMS ACHIEVEMENT DIVISION (STAD) DENGAN METODE MIND MAPPING PADA MATERI SEGIEMPAT DI KELAS VII SMP
}

\author{
Abriyanti Oktafiani \\ Pendidikan Matematika, Fakultas Matematika dan Ilmu Pengetahuan Alam, Universitas Negeri Surabaya, \\ e-mail:abriyantioktafiani@mhs.unesa.ac.id \\ Rini Setianingsih \\ Pendidikan Matematika, Fakultas Matematika dan Ilmu Pengetahuan Alam, Universitas Negeri Surabaya, \\ e-mail:rinisetianingsih@unesa.ac.id
}

\begin{abstract}
Abstrak
Keterampilan dalam memilih model dan metode pembelajaran yang tepat sangat penting untuk dikuasai oleh guru. Hal ini dilakukan agar pembelajaran dapat lebih menarik, mudah dipahami dan tentu saja dapat menunjang prestasi belajar peserta didik. Model pembelajaran yang diterapkan dalam penelitian ini adalah model pembelajaran kooperatif tipe STAD dengan metode Mind Mapping. Model pembelajaran kooperatif tipe STAD adalah salah satu tipe pembelajaran kooperatif yang menggunakan kelompok-kelompok kecil yang heterogen dengan jumlah anggota tiap kelompok 4-5 orang. Adapun metode Mind Mapping adalah teknik meringkas bahan yang perlu dipelajari dalam bentuk peta, gambar, grafik dan menggunakan warna agar lebih mudah memahaminya. Penelitian ini bertujuan untuk (1) mendeskripsikan aktivitas peserta didik dalam penerapan model pembelajaran kooperatif tipe STAD dengan metode Mind Mapping, (2) mendeskripsikan pengelolaan pembelajaran oleh guru, (3) mendeskripsikan hasil belajar peserta didik, dan (4) mendeskripsikan respon peserta didik terhadap penerapan model pembelajaran kooperatif tipe STAD dengan metode Mind Mapping. Penelitian ini merupakan penelitian deskriptif dengan pendekatan kualitatif dan kuantitatif. Data dikumpulkan dengan menggunakan teknik observasi, tes hasil belajar, dan angket respon peserta didik. Teknik observasi digunakan untuk memperoleh data tentang aktivitas pengelolaan pembelajaran guru dan aktivitas peserta didik, sedangkan teknik tes digunakan untuk memperoleh data tentang prestasi belajar. Dari hasil analisis deskriptif diperoleh beberapa hasil dari penerapan model pembelajaran kooperatif tipe STAD dengan metode Mind Mapping antara lain: (1) peserta didik aktif dalam mengerjakan tugas dan membuat Mind Mapping, hal ini ditunjukkan dengan hasil observasi aktivitas peserta didik dengan persentase 82,57\% pada kategori sangat baik; (2) aktivitas pengelolaan pembelajaran guru berjalan kondusif, hal ini dapat ditunjukkan dengan hasil observasi pengelolaan pembelajaran guru dengan persentase 79,52\% pada kategori baik; (3) tes hasil belajar peserta didik rendah hal ini dapat dilihat dari hasil tes peserta didik dengan persentase $10 \%$ pada kategori kurang sekali; dan (4) respon peserta didik dalam pembelajaran baik, dapat ditunjukkan dengan hasil angket respon peserta didik dengan persentase $53,95 \%$ pada kategori baik. Hasil penelitian menunjukkan bahwa penerapan model pembelajaran kooperatif tipe STAD dengan metode Mind Mapping pada peserta didik SMPN 3 Waru belum terlaksana dengan baik dikarenakan hasil belajar peserta didik yang masih kurang dari KKM.
\end{abstract}

Kata Kunci: Pembelajaran Kooperatif tipe STAD, Mind Mapping

\begin{abstract}
Skills in choosing the right model and learning method are very important to be mastered by the teacher. This is done so that learning can be more interesting, easy to understand and of course can support student learning achievement. The learning model applied in this study is the STAD type cooperative learning model with the Mind Mapping method. STAD type cooperative learning model is one type of cooperative learning that uses heterogeneous small groups with the number of members in each group 4-5 people. The Mind Mapping method is a technique of summarizing materials that need to be studied in the form of maps, images, graphics and using colors to make it easier to understand. This study aims to (1) describe the activities of students in the application of the STAD type cooperative learning model with the Mind Mapping method, (2) describe the management of learning by teachers, (3) describe the learning outcomes of students, and (4) describe the responses of students to the application of the STAD type cooperative learning model with the Mind Mapping method. This research is a descriptive study with qualitative and quantitative approaches. Data was collected using observation techniques, learning outcomes tests, and student response questionnaires. Observation techniques are used to obtain data about teacher learning
\end{abstract}


management activities and student activities, while test techniques are used to obtain data on learning achievement. From the results of the descriptive analysis obtained several results from the application of the STAD type cooperative learning model with the Mind Mapping method, among others: (1) active students in working on tasks and making Mind Mapping, this is indicated by observations of student activity with a percentage of $82.57 \%$ in the very good category; (2) teacher learning management activities run conducive, this can be indicated by observations of teacher learning management with a percentage of $79.52 \%$ in the good category; (3) test of student learning outcomes is low this can be seen from the test results of students with a percentage of $10 \%$ in the category less once; and (4) the response of students in good learning, can be indicated by the results of the questionnaire responses of students with a percentage of $53.95 \%$ in the good category. The results of the study showed that the application of the STAD type cooperative learning model with the Mind Mapping method on students of SMP 3 Waru had not been implemented properly because the learning outcomes of students who were still lacking were KKM.

Keywords: Cooperative Learning Type STAD, Mind Mapping

\section{PENDAHULUAN}

Perkembangan zaman pada era globalisasi saat ini semakin modern sehingga menuntut adanya sumber daya manusia yang berkualitas tinggi. Peningkatan sumber daya manusia merupakan salah satu prasyarat mutlak untuk mencapai suatu tujuan pembangunan. Sarana untuk meningkatkan kualitas sumber daya manusia salah satunya adalah pendidikan. Pendidikan merupakan usaha sadar untuk menumbuh kembangkan potensi sumber daya manusia melalui kegiatan pembelajaran.

Berdasarkan UU Sistem Pendidikan Nasional tahun 2003, tujuan pendidikan nasional adalah mencerdaskan kehidupan bangsa dan mengembangkan manusia Indonesia seutuhnya yaitu manusia yang bertakwa terhadap Tuhan Yang Maha Esa dan berbudi pekerti luhur, memiliki pengetahuan dan keterampilan, kesehatan jasmani dan rohani, kepribadian yang mantap dan mandiri serta tanggung jawab kemasyarakat dan kebangsaan. Pendidikan sendiri memiliki peran penting dalam mempersiapkan SDM yang berkualitas, yang mampu menghadapi serta berkompetisi dalam perkembangan ilmu pengetahuan dan teknologi. Salah satu ilmu yang digunakan untuk meningkatkan kualitas SDM adalah ilmu matematika.

Dalam pembelajaran matematika di sekolah, salah satu kompetensi lulusan yang diharapkan menurut Permendiknas No. 20 Tahun 2016 adalah agar setiap lulusan satuan pendidikan dasar dan menengah memiliki kompetensi pada tiga dimensi yaitu sikap, pengetahuan dan keterampilan. Pada kompetensi pengetahuan, terdapat tiga istilah pengetahuan yaitu faktual, konseptual, prosedural dan metakognitif pada masing-masing satuan pendidikan.

Dunia pendidikan tidak lepas dari komponenkomponen penting, salah satunya adalah adanya proses pembelajaran. Proses pembelajaran ini melibatkan dua subjek, yaitu guru sebagai fasilitator yang dapat memberikan pengetahuan dan peserta didik yang akan menghasilkan suatu perubahan pada diri sendiri sebagai hasil dari kegiatan pembelajaran. Penjelasan materi mata pelajaran matematika yang diberikan pada peserta didik seringkali dirasa menyulitkan peserta didik dalam memahaminya.

Berdasarkan observasi dan wawancara pada guru matematika SMPN 3 Waru Sidoarjo diketahui bahwa pada pembelajaran matematika guru cenderung menggunakan pembelajaran konvensional. Selain itu, dari hasil wawancara dengan guru dan peserta didik juga diperoleh informasi bahwa pada umumnya peserta didik mengerti pada saat guru menjelaskan, tetapi peserta didik sulit untuk mengungkapkan kembali dari apa yang telah dipelajari. Peserta didik mengerti pada saat guru memberikan contohcontoh soal dan penyelesaiannya, namun ketika dihadapkan dengan suatu masalah atau soal-soal yang berbeda dari contoh-contoh yang diberikan guru, peserta didik sulit untuk menentukan prosedur yang akan digunakan untuk menyelesaikannya. Hal ini dimungkinkan terjadi karena peserta didik hanya menghafal rumus ataupun mengetahui sesuatu tanpa memahami konsepkonsepnya secara mendalam.

Dari informasi tersebut, dapat diketahui bahwa peserta didik SMPN 3 waru Sidoarjo memiliki pemahamaan konsep yang masih rendah.

Pemikiran inilah yang menjadi dasar peneliti untuk memaksimalkan pelaksanaan proses pembelajaran melalui penerapan alternatif model dan metode pembelajaran dengan memaksimalkan pengelolaan, aktivitas, respon, dan hasil belajar peserta didik agar dapat memahami konsep materi yang disampaikan lebih baik serta menjadi sebuah inovasi baru dalam pembelajaran matematika.

Model pembelajaran kooperatif tipe STAD (Student Team Achievement Division) yang merupakan salah satu tipe pembelajaran kooperatif dengan menggunakan kelompok-kelompok kecil dengan jumlah anggota tiap kelompok 4-5 orang peserta didik secara heterogen. Salah satu metode pembelajaran yang dirasa cocok adalah mengubah metode pembelajaran agar menjadi lebih menarik bagi peserta didik yaitu metode yang dapat melibatkan kedua belahan otak. Metode yang dimaksud 
adalah metode Mind Mapping. Mind Mapping adalah suatu sketsa yang digunakan dalam menggambar ide-ide, katakata, atau hal-hal yang saling berkaitan satu sama lainnya dan tersusun secara radial mengelilingi kata kunci dari ide utama. Mind Mapping merupakan teknik meringkas bahan yang perlu dipelajari dalam bentuk peta, gambar, grafik, dan menggunakan warna agar lebih mudah memahaminya.

Metode yang diperkenalkan oleh Tony Buzan pada awal tahun 1970-an ini mengharuskan peserta didik untuk dapat menemukan dan menuliskan setiap informasiinformasi penting materi yang dipelajari secara menyeluruh dalam satu peta pikiran secara utuh. Oleh karena itu, pembelajaran dengan metode Mind Mapping akan menuntut peserta didik untuk terfokus pada setiap inti penting materi, yang akan mempermudah peserta didik dalam menguasai dan memahami konsep materi yang dipelajari. Metode Mind Mapping ini dapat mendorong guru dan peserta didik melaksanakan praktek pembelajaran secara aktif dan kreatif sehingga diharapkan tercapainya hasil belajar secara optimal. Pembelajaran dengan metode Mind Mapping akan lebih menyenangkan karena peserta didik dilatih untuk mengumpulkan informasi serta mampu mengomunikasikan informasi yang telah tersimpan di otaknya.

Berdasarkan uraian di atas, peneliti berasumsi bahwa penerapan model pembelajaran kooperatif tipe STAD dengan metode Mind Mapping akan meningkatkan hasil belajar peserta didik sebagai tujuan akhir pembelajaran yang akan dicapai. Hasil belajar dapat dikatakan sebagai suatu bentuk keberhasilan yang dicapai oleh peserta didik dalam proses pembelajaran dengan memahami konsep materi yang diajarkan. Jika hasil belajar peserta didik bagus, berarti penerapan metode tersebut dapat dikatakan berhasil. Hasil belajar peserta didik dinyatakan dalam bentuk angka yang diberikan oleh seorang guru kepada peserta didiknya sebagai bentuk penghargaan atas kesungguhan peserta didik dalam mengikuti proses belajar dan mengerjakan tugas yang telah diberikan guru. Materi yang digunakan dalam penelitian ini, adalah materi segiempat dengan subjek penelitian peserta didik kelas VII SMP.

Permasalahan dalam penelitian ini adalah: (1) bagaimana aktivitas belajar peserta didik dalam penerapan model pembelajaran kooperatif tipe STAD dengan menggunakan metode Mind Mapping pada materi Segiempat di kelas VII SMP, (2) bagaimana kemampuan guru mengelola pembelajaran dengan penerapan model pembelajaran kooperatif tipe STAD dengan menggunakan metode Mind Mapping pada materi Segiempat di kelas VII SMP, (3) bagaimana hasil belajar peserta didik saat penerapan model pembelajaran kooperatif tipe STAD dengan menggunakan metode Mind Mapping pada materi Segiempat di kelas VII SMP, (4) bagaimana respon peserta didik dalam penerapan model pembelajaran kooperatif tipe STAD dengan menggunakan metode Mind Mapping pada materi Segiempat di kelas VII SMP.

\section{METODE}

Penelitian ini merupakan penelitian deskriptif dengan pendekatan kuantitatif dan kualitatif. Pendekatan penelitian kuantitatif digunakan untuk mengolah data hasil penilaian pelaksanaan pembelajaran berupa data observasi kemampuan guru mengelola pembelajaran, data observasi aktivitas peserta didik, tes hasil belajar, dan angket respon peserta didik, sedangkan pendekatan kualitatif digunakan untuk mendeskripsikan pengelolaan guru pada saat pelaksanaan pembelajaran, aktivitas peserta didik, hasil belajar peserta didik serta respon peserta didik saat pelaksanaan pembelajaran menggunakan model pembelajaran kooperatif tipe STAD dengan metode Mind Mapping dari penelitian yang dilakukan. Penelitian ini dilaksanakan di kelas VII-C SMP Negeri 3 Waru Sidoarjo, dengan banyak peserta didik 32 orang. Dari 32 orang tersebut dipilih 4 orang sebagai subjek penelitian secara heterogen.

Instrumen yang digunakan dalam penelitian ini terdiri dari instrument utama berupa peneliti sendiri dan instumen pendukungnya berupa lembar observasi pengelolaan pembelajaran, lembar observasi aktivitas peserta didik, angket respon peserta didik, dan pedoman wawancara.

Subjek pada penelitian ini diperoleh dari memilih dua kelompok belajar secara heterogen yang kemudian diberikan tes kepada seluruh peserta didik kelas VII-C. Dari dua kelompok belajar tersebut, peneliti memilih peserta didik dari masing-masing kelompok dengan perolehan nilai tertinggi dan terendah dalam kelompok. Pada setiap pertemuan, peneliti akan memberikan tes dan penilaian tersendiri, dari sinilah data keterlaksanaan pembelajaran dan hasil belajat peserta didik diperoleh. Data hasil persentase keterlaksanaan pembelajaran dan data hasil persentase hasil belajar peserta didik kemudian dianalisis dengan menggunakan rentang skor dengan perhitungan yang merujuk Winarni (2015). Adapun kriteria lembar observasi kegiatan pembalajaran dan hasil belajar secara klasikal yang digunakan dalam penelitian ini antara lain:

Tabel 1. Kriteria Hasil Observasi Kegiatan Pembelajaran

\begin{tabular}{|c|c|c|}
\hline No & Persentase & Kategori \\
\hline 1 & $80 \% \leq \mathrm{P}_{1} \leq 100 \%$ & Sangat Baik \\
\hline 2 & $60 \% \leq \mathrm{P}_{1}<80 \%$ & Baik \\
\hline 3 & $40 \% \leq \mathrm{P}_{1}<60 \%$ & Cukup \\
\hline 4 & $0 \% \leq \mathrm{P}_{2}<40 \%$ & Kurang \\
\hline
\end{tabular}

Tabel 2 Kriteria Hasil Belajar secara Klasikal

\begin{tabular}{l|l|l} 
No & Persentase & Kategori \\
\hline
\end{tabular}




\begin{tabular}{|c|c|c|}
\hline 1 & $80 \% \leq \mathrm{P}_{2} \leq 100 \%$ & Baik Sekali \\
\hline 2 & $60 \% \leq \mathrm{P}_{2}<80 \%$ & Baik \\
\hline 3 & $40 \% \leq \mathrm{P}_{2}<60 \%$ & Cukup \\
\hline 4 & $20 \% \leq \mathrm{P}_{2}<40 \%$ & Kurang \\
\hline 5 & $0 \% \leq \mathrm{P}_{2}<20 \%$ & Kurang Sekali \\
\hline
\end{tabular}

Tabel 3 Kriteria Skor Angket Respon Peserta Didik

\begin{tabular}{|c|c|}
\hline Skor Total & Kategori \\
\hline $75 \% \leq P_{3} \leq 100 \%$ & Sangat Baik \\
\hline $50 \% \leq P_{3}<75 \%$ & Baik \\
\hline $0 \% \leq P_{3}<50 \%$ & Kurang Baik \\
\hline
\end{tabular}

Keterangan:

$\mathrm{P}_{1}$ adalah persentase keterlaksanaan pembelajaran

$\mathrm{P}_{2}$ adalah persentase hasil belajar peserta didik.

$\mathrm{P}_{3}$ adalah persentase angket respon peserta didik

Selanjutnya, data yang diperoleh dapat dianalisis dengan menggunakan pendekatan kuantitatif dan kualitatif berdasarkan indikator yang telah ditentukan sebelumnya. Untuk melengkapi informasi mengenai pelaksanaan pembelajaran dan penerapan metode Mind Mapping dilakukan wawancara. Hasil wawancara dianalisis melalui tahap kondensasi data, penyajian data, dan penarikan kesimpulan.

\section{HASIL DAN PEMBAHASAN}

Berdasarkan analisis data hasil belajar peserta didik dan wawancara yang telah dilakukan, diperoleh hasil dan pembahasannya sebagai berikut.

1. Aktivitas belajar peserta didik dalam menerapkan model pembelajaran kooperatif tipe STAD dengan menggunakan metode Mind Mapping

Dalam proses pembelajaran di kelas, ada beberapa peserta didik yang aktif dan banyak peserta didik yang pasif. Akan tetapi pembelajaran tetap terlaksana dengan baik. Terdapat beberapa indikator penilaian yang tidak terlaksana dengan baik dalam setiap pertemuan oleh peserta didik, diantaranya adalah beberapa peserta didik yang pasif dalam belajar, tidak adanya tanggapan atau komentar terhadap hasil yang dipresentasikan oleh kelompok lain, peserta didik mengerjakan tes individu dengan berdiskusi atau menyontek dengan teman sebangku sedangkan harusnya mengerjakan secara individu, peserta didik kesulitan dalam mengaplikasikan Mind Mapping dalam pembelajaran dikarenakan tidak pernah menggunakan Mind Mapping sebelumnya, dan banyaknya perilaku peserta didik yang tidak sesuai dengan kegiatan pembelajaran seperti bermainmain, tidur, melamun, berbicara tidak berkaitan dengan materi pelajaran, jalan-jalan ke kelompok lain, gaduh dsb. Hal ini mempengaruhi pada kemampuan peserta didik dalam memahami dan menguasai materi dan mengakibatkan hasil belajar peserta didik menjadi rendah dan dibawah KKM yang telah ditentukan sebelumnya.

Hal ini didukung oleh hasil penelitian yaitu , data hasil aktivitas belajar peserta didik dalam penerapan model pembelajaran kooperatif tipe STAD dengan menggunakan metode Mind Mapping adalah $82,57 \%$ persentase untuk pertemuan pertama adalah untuk kelompok 4 adalah $75 \%$ dan kelompok 5 adalah $86,36 \%$. Pada pertemuan kedua untuk kelompok 4 adalah $81,81 \%$ dan kelompok 5 adalah $84,09 \%$, sedangkan pada pertemuan ketiga untuk kelompok 4 adalah $81,81 \%$ dan kelompok 5 adalah 86,36\%. Untuk rara-rata aktivitas peserta didik pada kelompok 4 adalah 79,54\% dengan kategori baik, sedangkan pada kelompok 5 memiliki rata-rata $85,60 \%$ dengan kategori sangat baik. Hal ini menunjukkan bahwa keterlaksanaan pembelajaran dengan model dan metode yang digunakaan sudah terlaksana dengan baik, dapat dilihat dari aktivitas belajar peserta didik yang masuk pada kategori baik.

2. Pengelolaan pembelajaran guru dalam menerapkan model pembelajaran kooperatif tipe STAD dengan menggunakan metode Mind Mapping

Dalam proses pembelajaran di kelas, ada beberapa indikator penilaian terhadap guru yang belum terlaksana dengan baik dalam setiap pertemuan, seperti guru belum menghasilkan apersepsi dengan menarik, guru tidak terlalu menguasai materi pembelajaran, guru masih terlihat bingung dalam mengaitkan materi dengan pengetahuan lain yang relavan, serta guru kurang mampu menumbuhkan keceriaan dan antusiasme peserta didik dalam belajar. Hal ini mempengaruhi hasil belajar peserta didik di akhir pembelajaran yang mengakibatkan hasil belajar hasil belajar peserta didik dibawah KKM.

Hal ini didukung melalui hasil penelitian, yaitu data hasil kemampuan guru dalam mengelola pembelajaran kooperatif tipe STAD dengan menggunakan metode Mind Mapping adalah 79,92\%. Persentase untuk pertemuan pertama adalah $79,54 \%$ dan pertemuan kedua adalah $81,81 \%$, sedangkan persentase pada pertemuan ketiga yaitu $78,40 \%$. Untuk rara-rata keseluruhan kemampuan guru mengelola pembelajaran selama pembelajaran segiempat 
berlangsung adalah 79,92\% dengan kategori baik. Hal ini menunjukkan bahwa keterlaksanaan pengelolaan guru pada model pembelajaran kooperatif tipe STAD dengan metode Mind Mapping sudah terlaksana dengan baik.

3. Hasil belajar peserta didik dalam menerapkan model pembelajaran kooperatif tipe STAD dengan menggunakan metode Mind Mapping Hasil belajar peserta didik kelas VII-C diperoleh dari tes yang dilakukan pada akhir pertemuan. Jumlah butir soal tes adalah 6 nomor. Tes dikerjakan oleh 30 peserta didik kelas VII-C. Tes dikerjakan peserta didik dengan durasi 40 menit. Materi yang digunakan dalam tes terkait dengan materi segiempat yang telah diajarkan menggunakan model pembelajaran kooperatif tipe STAD dengan metode Mind Mapping.

Berdasarkan tes yang dilakukan, diperoleh data seperti yang ada pada penyajian data. Dari data tersebut diketahui bahwa ada 3 peserta didik yang telah lulus KBM dan selebihnya yaitu 29 peserta didik dibawah KKM. Namun sesuai dengan kriteria hasil belajar secara klasikal, hasil belajar peserta didik kelas VII-C SMPN 3 Waru Sidoarjo dikategorikan kurang sekali dengan persentase ketuntasan tes hasil belajar secara klasikal 10\%, hal ini jauh dari apa yang diharapkan dalam penelitian ini, dimana pada kriteria hasil belajar secara klasikal terdapat pada kategori yang rendah yaitu dengan nilai hasil belajar peserta didik kurang dari $20 \%$. Hal tersebut berbanding terbalik dengan penelitian yang dilakukan oleh Maria Rosaria (2017) yang berjudul "Pengaruh Penerapan Metode Mind Mapping Terhadap Hasil Belajar Siswa Kelas CI Di SMA Negeri 2 Yogyakarta Tahun Ajaran 2016/2017 Pada Mata Pelajaran Matematika Materi Statistika”. Penelitian yang dilakukan Maria menyimpulkan bahwa model pembelajaran STAD dengan metode Mind Mapping memberi pengaruh terhadap hasil belajar peserta didik dan guru dapat menerapkan metode yang sama pada materi lainnya karena metode Mind Mapping memberikan pengaruh positif selama pembelajaran di kelas.

Penerapan model dan metode pembelajaran menurut hasil observasi kemampuan guru, aktivitas peserta didik, dan wawancara menunjukkan hasil yang positif dalam penelitian ini. Namun pada hasil tes belajar berbanding terbalik, karena nilai peserta didik banyak yang dibawah KBM. Peserta didik berpendapat bahwa soal yang diberikan oleh peneliti berbanding terbalik dengan soal yang biasa diberikan oleh guru matematika di sekolah tersebut. Peserta didik mengganggap bahwa soal yang diberikan sangat sulit dan perlu bimbingan lebih untuk memahami lebih jauh soal yang dibuat peneliti. Padahal pada saat validasi, guru mengganggap bahwa peserta didik mampu mengerjakan soal yang dibuat oleh peneliti. Akibatnya tes hasil belajar peserta didik menjadi rendah dan hanya tiga peserta didik saja yang berhasil nilainya sesuai KBM yang ditentukan. Oleh karena itu, untuk mengevaluasi hasil belajar peserta didik dengan model pembelajaran kooperatif tipe STAD maka guru lebih mengenalkan peserta didik dengan masalahmasalah matematika, tidak hanya dengan mengenal rumus matematika saja tanpa menghubungkan dengan masalah kontekstual yang ada sehingga peserta didik tidak kesulitan lagi dalam mengerjakan soal/ masalah matematika kontekstual.

Berdasarkan hasil pengamatan, wawancara, dan observasi terkait penerapan metode Mind Mapping selama pembelajaran berlangsung, kebanyakan peserta didik memberikan respon yang baik terhadap metode Mind Mapping. Walaupun mendapat respon yang baik dalam penerapan metode Mind Mapping, namun peneliti mengganggap bahwa penelitian yang dilakukan memiliki hasil yang masih belum sesuai dengan yang diharapkan, yaitu ketuntasan hasil belajar peserta didik saat penerapan metode Mind Mapping tergolong rendah yaitu hanya 3 peserta didik saja yang dapat tuntas dari nilai KKM.

Dalam wawancara terhadap beberapa subjek penelitian, salah satu peserta didik mengungkapkan bahwa mereka baru mengetahui mengenai metode Mind Mapping dalam materi matematika, oleh karena itu peserta didik masih sedikit susah dalam mengaplikasikan metode Mind Mapping. Hal berbeda diungkapkan oleh peserta didik lainnya, bahwa ia lebih mudah memahami materi dan mempelajari materi dengan metode Mind Mapping. Ia mengungkapkan bahwa metode ini, tidak membosankan dan unik, selain itu peserta didik menyarankan untuk lebih sering mengggunakan metode Mind Mapping kepada peserta didik sebagai salah satu alternatif metode pembelajaran yang akan digunakan pada materi matematika selanjutnya.

4. Respon peserta didik dalam menerapkan model pembelajaran kooperatif tipe STAD dengan menggunakan metode Mind Mapping 
Data respon peserta didik diperoleh dari lembar angket yang telah diisi oleh 27 peserta didik kelas VII-C. Angket respon peserta didik terdiri dari 15 pernyataan dengan skala penilaian " 1 untuk tidak setuju", "2 untuk kurang setuju", "3 untuk setuju" dan "4 untuk sangat setuju". Setiap pernyataan dalam angket tersebut berkaitan dengan pembelajaran yang telah diterapkan selama tiga pertemuan terakhir.

Dilihat dari masing-masing indikator penilaian, respon terhadap pembelajaran kelompok memiliki persentase $73,75 \%$ dimana masuk pada kateogi baik sehingga dapat disimpulkan bahwa kebanyakan peserta didik kelas VII-C senang apabila menggunakan pembelajaran kelompok dalam proses pembelajaran. Pada indikator selanjutnya mengenai respon peserta didik terhadap kerjasama kelompok memiliki persentase $75,75 \%$ dimana persentase tersebut masuk dalam kategori sangat baik. Respon peserta didik terhadap kerjasama kelompok sangat baik dalam tiga pertemuan, mereka berdiskusi dalam menjawab pertanyaan-pertanyaan yang ada pada LKPD sehingga nilai pada LKPD tinggi-tinggi tiap kelompok. Sedangkan pada indikator penilaian terakhir yaitu respon peserta didik terhadap keseluruhan proses pembelajaran adalah $66,70 \%$. Respon ini merupakan respon terendah dari indikator lain. Hal ini dikarenakan peserta didik kesulitan dalam memahami materi pembelajaran. Soal-soal yang diberikan peneliti dianggap sulit oleh peserta didik dikarenakan mereka tidak pernah diberikan soal mengenai pemecahan masalah. Hal ini membuat peserta didik menjadi malas dalam mengerjakan tugas yang telah diberikan, dan hanya beberapa orang di dalam kelompok yang mengerjakan tugas LKPD tersebut. Mereka jadi tidak memahami materi, karena dari awal mereka terlalu bingung dalam mengerjakan soal tersebut dan berakibat respon yang buruk dalam pembelajaran.

\section{PENUTUP}

\section{Simpulan}

1. Aktivitas peserta didik pada saat penerapan model pembelajaran kooperatif tipe STAD dengan menggunakan metode Mind Mapping, mengalami naik turun. Pada pertemuan pertama, aktivitas peserta didik pada kelompok 4 memiliki persentase $75 \%$ dengan kategori baik sedangkan kelompok 5 dengan persentase $86,36 \%$ dengan kategori sangat baik. Perbedaan aktivitas kedua kelompok peserta didik tersebut sangat signifikan. Pada pertemuan kedua, aktivitas peserta didik kelompok 4 telah mengalami peningkatan dengan persentase $81,81 \%$ dan masuk kategori sangat baik, hal ini tidak berlaku pada kelompok 5 yang mengalami penurunan aktivitas yaitu dengan persentase $84,09 \%$ walaupun masih masuk kategori sangat baik. Untuk pertemuan observasi terakhir, yaitu pertemuan ketiga aktivitas peserta didik kelompok 4 tidak mengalami peningkatan. Dengan kata lain, persentase aktivitas peserta didik kelompok 4 sama dengan pertemuan sebelumnya, yaitu 81,81\%. Pada kelompok 5, aktivitas peserta didik mengalami peningkatan lagi dengan persentase $86,36 \%$. Hal ini menunjukkan bahwa peserta didik memiliki respon baik dalam menggunakan model dan metode pembelajaran yang digunakan peneliti walaupun hasil akhirnya masih belum maksimal. Hal ini dibuktikan dengan persentase keseluruhan aktivitas peserta didik adalah $82,57 \%$ dengan kategori sangat baik.

2. Keterlaksanaan pengelolaan pembelajaran oleh guru dengan menggunakan model dan metode dalam penelitian ini baik/efektif. Pada pertemuan pertama dengan persentase $79,54 \%$ dengan kategori baik, indikator penilaian semua telah terlaksana namun masih belum dimaksimalkan oleh guru. Pada pertemuan kedua, persentasenya adalah $81,81 \%$ dengan kategori sangat baik, indikator penlaian telah dimaksimalkan sebaik mungkin oleh guru. Pertemuan ketiga persentasenya adalah $78,40 \%$ dengan kategori baik,persentase ini mengalami penurunan dari pertemuan satu dan dua. Indikator yang tidak dilakukan dengan baik pada pertemuan ini adalah guru masih belum mampu mengaitkan materi layang-layang dan trapesium dengan pengetahuan lain yang relavan. Secara keseluruhan, peneliti yang bertindak sebagai guru sudah dinilai mampu melaksanakan pembelajaran sesuai dengan langkah-langkah pembelajaran yang telah dirancang sebelumnya sesuai dengan aspek penilaian dengan rata-rata persentase kemampuan pengelolaan pembelajaran guru adalah 79,92\% dengan kategori baik.

3. Tes hasil belajar peserta didik setelah menerapkan model pembelajaran kooperatif tipe STAD dengan metode Mind Mapping pada peserta didik kelas VII-C SMPN 3 Waru Sidoarjo secara persentase ketuntasan secara 
klasikal adalah $10 \%$, hal ini jauh dari apa yang diharapkan dalam penelitian ini, dimana persentase klasikal peserta didik kurang dari 20\% dan masuk kategori kurang sekali.

4. Respon peserta didik memperoleh hasil yang positif pada setiap indikator penilaian. Terdapat tiga indikator penilaian dalam angket respon peserta didik. Pada indikator pertama yaitu mengenai respon peserta didik terhadap belajar kelompok, persentase respon yang diberikan peserta didik adalah 73,35\% dan masuk kategori sangat baik. Pada indikator kedua, yaitu respon peserta didik terhadap kerjasama kelompok, persentase respon yang diberikan peserta didik adalah $75,75 \%$ dan juga masuk dalam kategori sangat baik. Sedangkan untuk indikator terakhir yaitu respon peserta didik terhadap keseluruhan proses pembelajaran mendapat persentase respon peserta didik $66,70 \%$. Hasil persentase rata-rata keseluruhan indikator penilaian dalam respon peserta didik adalah 53,95\% dengan kategori baik. Hal Ini membuktikan bahwa ada sebagian peserta didik yang ingin menerapkan model pembelajaran kooperatif tipe STAD dengan metode Mind Mapping dalam pembelejaran selanjutnya. Mereka mengatakan lebih memahami materi pelajaran jika menggunakan metode tersebut, karena mereka hanya mempelajari inti dari materi saja.

\section{Saran}

Berdasarkan hasil penelitian yang telah diperoleh, peneliti memberikan saran sebagai berikut.

1. Model pembelajaran kooperatif tipe STAD dengan metode Mind Mapping dapat dijadikan alternatif model pembelajaran dan metode yang dapat diterapkan dalam mengajar, karena dengan metode Mind Mapping peserta didik dapat mengkreasikan ide dan gagasannya berdasarkan pemikiran dan pemahaman mereka sendiri sehinggan lebih mempermudah peserta didik dalam memahami materi yang disampaikan dan dapat diingat dalam jangka waktu lama.

2. Perlu adanya suasana kompetitif atau daya saing antar kelompok belajar selama proses pembelajaran agar dapat memberikan semangat belajar yang lebih tinggi dan dapat meningkatkan suasana kelas yang mendorong peserta didik untuk berlomba-lomba dalam menyelesaikan tugas dengan baik.

3. Kepada para peneliti selanjutnya diharapkan dapat melakukan penelitian tentang penerapan model pembelajaran kooperatif tipe Student Teams Achievement Divisions (STAD) dengan metode Mind Mapping, dengan hasil belajar yang lebih baik lagi.

\section{DAFTAR PUSTAKA}

Buzan,T.2004.Buku Pintar Mind Map.Jakarta:PT. Gramedia Pustaka Utama

Depdiknas. 2003. Undang-Undang RI No.20 Tahun 2003 Tentang Sistem Pendidikan Nasional. Jakarta: Depdiknas.

Depdiknas. 2016. Peraturan Menteri Pendidikan dan Kebudayaan Nomor 20 Tahun 2016 Tentang Standar Kompetensi Lulusan Pendidikan Dasar dan Menengah. Jakarta: Depdiknas.

Hasanah S. I., Jannah U.R. 2013. "Penggunaan Metode Mind Mapping untuk Meningkatkan Hasil Belajar Siswa Pada Materi Segiempat”. Jurnal Universitas Madura. KNPM V, Himpunan Matematika Indonesia. hal. 2-3.

Kristanto, Ignasius. 2017. Penerapan Model Pembelajaran Kooperatif Tipe Student Teams-Achievements Divisions (Stad) Untuk Meningkatkan Hasil Belajar Siswa Pada Mata Pelajaran Teknologi Dasar Otomotif (Tdo) Kelas X Di Smk Ma'arif Salam. Skripsi tidak diterbitkan. Yogyakarta: Universitas Negeri Yogyakarta.

Olivia, Femi. 2014. 5-7 Menit Asyik Mind Mapping Pelajaran Sekolah. Jakarta: PT Elex Media Komputindo.

Setianingsih, R. 2018. Bahan Ajar Mata Kuliah Metodologi Penelitian. Surabaya: STAI YPBWI Press.

Winarni. 2015. Penerapan Model Pembelajaran Langsung dengan Mind Mapping untuk Meningkatkan Hasil Belajar IPS Materi Pokok Perkembangan Teknologi di Kekas IV SD Karen Bantul. Tesis tidak diterbitkan. Surabaya: Universitas Negeri Surabaya. 